LOCAL WISDOM, 13 (2): 165-151, 2021
Local Wisdom Scientific Online Journal
ISSN: 2086-3764

\title{
Limbungan Local Wisdom and Conservation of Vernacular Architecture East Lombok Sasak
}

\author{
Dendi Sigit Wahyudi ${ }^{*}$, Respati Wikantiyoso ${ }^{2}$ \\ ${ }^{1}$ Magister Architecture, University of Brawijaya, Malang, Indonesia \\ ${ }^{2}$ Department of Architecture, University of Merdeka Malang, Indonesia \\ Corresponding Author: dendiwahyudi6@gmail.com
}

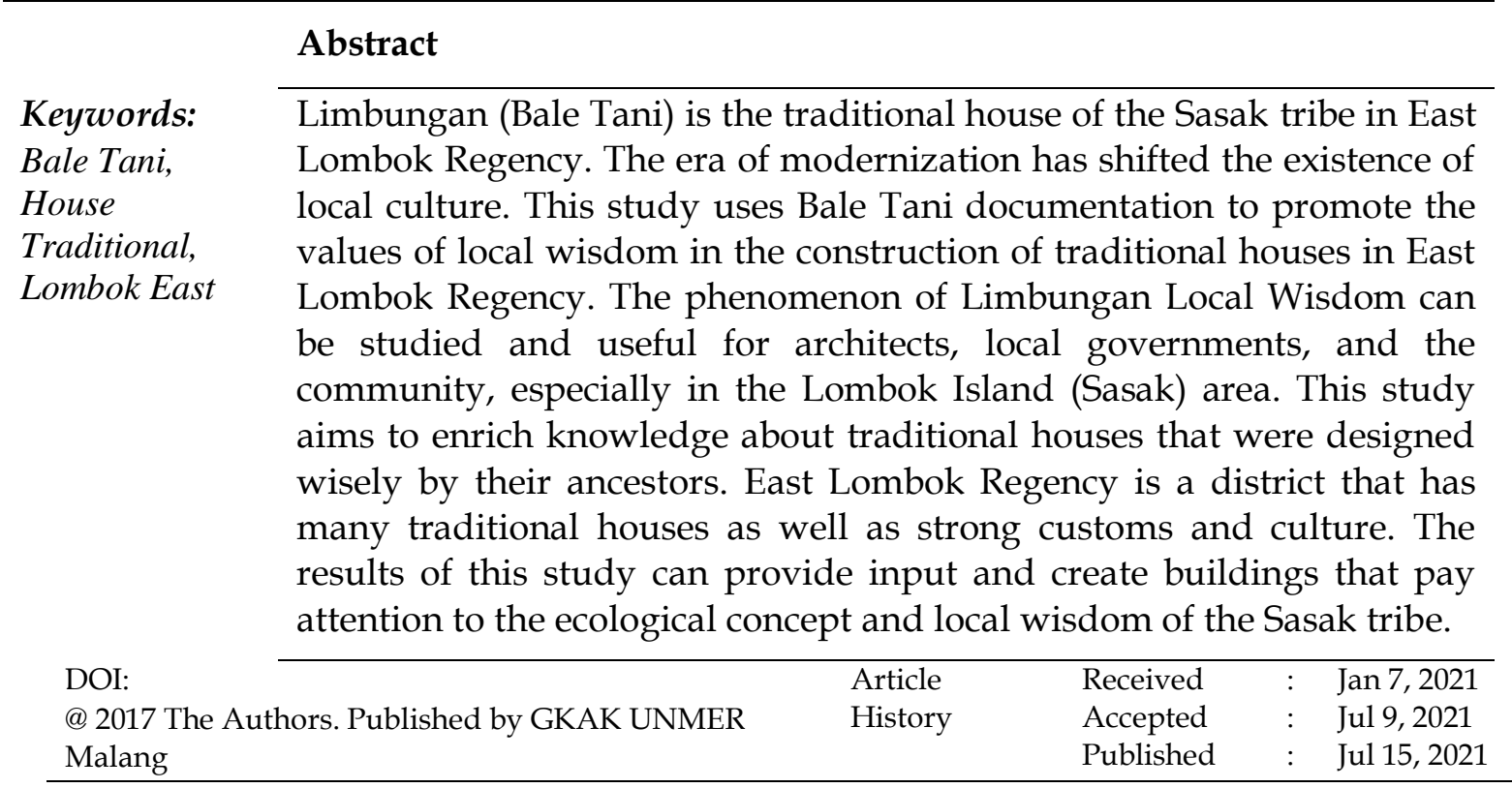

\section{INTRODUCTION}

Bale Tani is a traditional house of limbungan located in East Lombok Regency with bamboo construction as its building material. Bale tani is a traditional house located in the Rinjani mountain area or under the foot of Mount Rinjani. The embodiment of the limbungan traditional house is one form of Vernacular Architecture. According to (Suharjanto, 2011), vernacular architecture is a term used to categorize construction methods that use local indigenous resources to meet local needs that reflect the environment, culture, and history in which they are located (I. Hilman \& Hendriawan, 2018). This architectural work is based on a trial and error (intuition) approach passed down from generation to generation. The traditional house of limbungan has developed rapidly in terms of its environment, culture, and history. In its construction, Bale Tani is not bound by certain sizes and dimensions. This is what makes the Bale Tani building included in the vernacular architectural style. According to (Tanudirjo et al., 2019), preservation should be seen as an effort to re-actualize cultural heritage (Golany, 1995; I. Hilman \& Hendriawan, 2018; Iman Hilman \& Sunaedi, 2017) in the context of the current system. Preservation (Álvarez-García et al., 2019; Titisari, 2017) must also accommodate 
the possibility of change because preservation must be seen to give new meaning to the cultural heritage itself (Widayati, 2002).

Limbungan Hamlet, located at Mount Rinjani's foot, has a traditional house area that occupies two places, namely East Limbungan with 68 housing units and West Limbungan with 71 housing units. The two dwellings are bordered by live plants and a rough woven bamboo fence called kampu (Border). Their houses are woven bamboo walls, dirt floors mixed with buffalo dung, alang-alang roof, with a frame construction of a mixture of wood and bamboo. With the development of technology and the advancement of modernization (I. Hilman \& Hendriawan, 2018), the village's local culture, the village can be displaced by its advantages. Cultural shifts can occur in both urban and rural areas. The Limbungan people in Bale Tani are mostly from their ancestors (Sesepuh/Toak). The younger generation can also live in this Limbungan traditional house. The Bale Tani traditional house building is a form of physical culture that cannot be built with the original rules technological advances in the 4.0 era.

Therefore, this research was conducted to find out about Bale Tani, and find out the values of local wisdom in Bale Tani and become knowledge for the Limbungan community itself. Furthermore, research can reproduce work as well as knowledge about traditional Indonesian houses that design traditional architecture in the country. Traditional architecture in the archipelago has different designs due to different natural conditions and traditional buildings that have been preserved from time to time.

\section{LITERATURE STUDY}

Local wisdom is the identity or cultural personality of a nation that causes the nation to be able to absorb, even cultivate culture from outside/other nations into its character and abilities (Widiana \& Wikantiyoso, 2018). The identity and personality (Iman Hilman et al., 2019)adjust to the live view of the surrounding community so that there is no shift in values. Local wisdom is one way to cultivate and defend oneself from foreign cultures that are not good.

Local wisdom is a view of life and knowledge, and various life strategies in the form of activities carried out by local communities in responding to various problems in meeting their needs. In foreign languages, it is often too conceptualized as local wisdom or local knowledge, "local knowledge" or local genius (Fajarini, 2014).

\section{Forms of Local Wisdom}

Haryanto, (2014) Sates that local wisdom is religious harmony in social practices based on cultural wisdom. The form of local wisdom in society can be culture (values, norms, ethics, beliefs, customs, customary laws, and special rules). Noble values related to local wisdom include love for God almighty and its contents (Raihani et al., 2015), responsibility, discipline, independence, honesty, respect and courtesy (I. Hilman \& Hendriawan, 2018), compassion and caring, confidence, creative, hard work, and unyielding, Justice and leadership, Kindship and humility, tolerance, love of peace, and unity .

\section{Local Wisdom of the Sasak Tribe (Sasak Community)}

Peace and harmony are very dominant cultures for the Sasak people. The Sasak people are known for their peaceful environment. The concept applied by the Sasak people is the Ajani concept which means mutual respect for fellow human beings. The Sasak people are known for their mutual tolerance, which adds to the local wisdom of the Lombok people in undergoing socialization between fellow humans. The Sasak people 
have long known the container, which is the mother of society life, about being guided by community life and the meeting place of a reference and setting sanctions or violations in the community's social values (Haryanto, 2014; I. Hilman \& Hendriawan, 2018). The container in question is krama. In the daily life of the Sasak people, conceptually, krama is a custom that includes local wisdom, which consists of two kinds, krama as a traditional institution and krama as rules that exist in society or social rules. In the Sasak indigenous people, there is ajikrama which means the value of holiness. Thus, ajikrama is a traditional symbol which means it has a sacred value for the social strata of the Sasak indigenous people based on their traditional territory. The explanation of ajikrama (traditional symbols), which contain the meaning of sacred values, is divided into two, namely:

1. Krama as a traditional institution consists of several parts, namely:

a. Krama Gubuk has the meaning of customary manners whose members are all community members in a hamlet, village, and dasan without exception, and the administration concerned is the resident registered in the hut.

b. Krama Banjar urip pati has a traditional group or community association whose members consist of village/hamlet residents whose members have the same goal. There are several types of krama banjar urip pati, namely krama banjar haji, krama banjar mate, krama banjar merariq and krama banjar subak.

c. Krama Desa is a village-level customary assembly consisting of pemusungan (customary village head), interpreter (assistant village head), lang - lang desa (village security head), a prosecutor (village judge), village welfare coordinator. (escape), and Kiai penghulu.

2. Courtesy as a rule of social interaction, there are several parts, namely:

a. The language of character is manners, manners, manners, and rules regulated in customary awik - awik, which must be carried out using body language, which means polite and orderly, and spoken language carried out in an orderly manner.

b. Titi Krama is a custom that has been regulated in awik - awik due to the customer agreement of all indigenous peoples. If violated, it will be subject to social or moral sanctions. Moral sanctions can be interpreted as ejiran (neighboring) customs and nyangkok customs (living at a lover's or boyfriend's house).

c. Aji Krama is traditional values or the value of the dignity of one's kinship (community) related to ulayat rights in the Sasak indigenous people, namely the usual norm of the community or the value of one's kinship (community) dignity related to ulayat rights in the Sasak indigenous community.

\section{Architectural Conservation}

Conservation is generally defined as preservation, but it has a series of meanings with different implications in the realm of conservationists. According to J, Widodo (2006), the term conservation commonly used by architects refers to the 1981 Charter for the International Council of Monuments and Sites or ICOMOS (Titisari, 2017), namely: Charter for the Conservation of Places of Cultural Significance, Burra, Australia.

According to Theodore Rooselvest (Milton, 2021), it means conservation itself derived from the word Conservation, which consists of the words con (together) and serve (keep \& save), which has an understanding of efforts to maintain what we have 
(keep \& save what you have). He was the first American to put forward the concept of conservation in general. In addition, according to Sidharta and Budihardjo (1989), "conservation is an effort to preserve buildings or the environment, regulate their use and direction of development according to current and future needs in such a way that their cultural meaning is maintained"

\section{RESEARCH METHODS}

This research was conducted using the descriptive-analytic method, which was carried out through the following stages:

1. The descriptive-analytical method is used to obtain interpretations of both primary data and secondary data.

2. Primary data obtained through observation. The observation technique is a complex way of collecting data which is carried out by direct observation in the field and systematic recording.

3. Secondary data is obtained from library sources such as books, journal libraries, theses, theses, both print media and electronic media (internet).

\section{DISCUSSION}

\section{Limbungan Traditional House}

Like a name as a person's identity, architectural works can become an identity in the Nusantara Architecture and people in Indonesia. The emergence of the traditional house of Limbungan (Bale Tani) in the sub-district of Suela, the cistern village, is the traditional house's identity in the district of East Lombok. This traditional house has been designated as a cultural village in East Lombok Regency, by the East Lombok government, as a traditional building with a traditional house. Moreover, socio-cultural uniqueness, which is still very strong. The Limbungan hamlet needs attention because it is historical cultural heritage potentials, philosophical, artistic, and cultural values for the indigenous people of the Limbungan itself. By establishing the traditional house of Limbungan as a cultural heritage, the extinction of a monument and remnants of the old culture can be avoided (Soeroto, 2003). Therefore, conservation is one way to anticipate changes and developments that occur, which is very necessary (Budihardjo \& Sidharta, 1989).

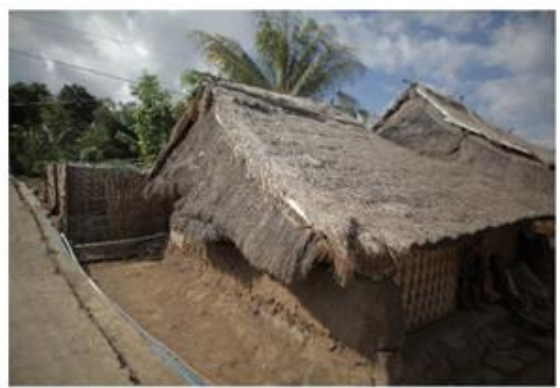

Figure 1. Bale tani traditional house (Author, 2020)

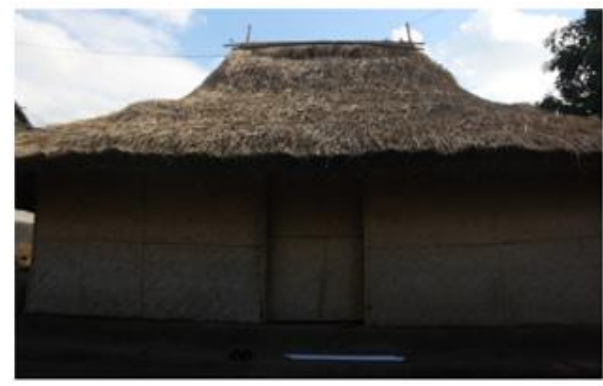

Figure 2. Bale tani traditional house (Author, 2020)

Building a Bale Tani is carried out in cooperation following the customs and traditions of the Limbungan indigenous community. The people are already lingsir (elders), and men are still young to build this Limbungan traditional house. As for the construction steps, according to observations and the people there, the traditional village 
community of Limbungan collects building materials used to build houses, such as bamboo, reeds (ijuk), wood, and soil that is overgrown with cow or buffalo dung. After collecting building materials for the traditional house, then erect the building poles. The pillars of the Limbungan traditional house are rectangular, and the shape of the house is simple and looks very light with a pole size of $15 \mathrm{~cm} \times 15 \mathrm{~cm}$ with a length of approximately 2 - 2.5 meters. After installing the poles, the building, then the poles are attached to the bedek (woven bamboo) that surrounds the poles. Then the next step is to assemble the roof with reeds (ijuk) and tied bamboo to install or place the roof of the building.

When viewed from the front, the roof of the building is similar to a pyramid roof. The roof is more significant than the body of the house. For roof installation, the length of the upper roof of the building is approximately 3 meters, and the length of the lower roof is approximately 6-7 meters (Fig.3). Then the distance between the roof and the ground is not too far, about 1.5 to 2 meters from the ground.
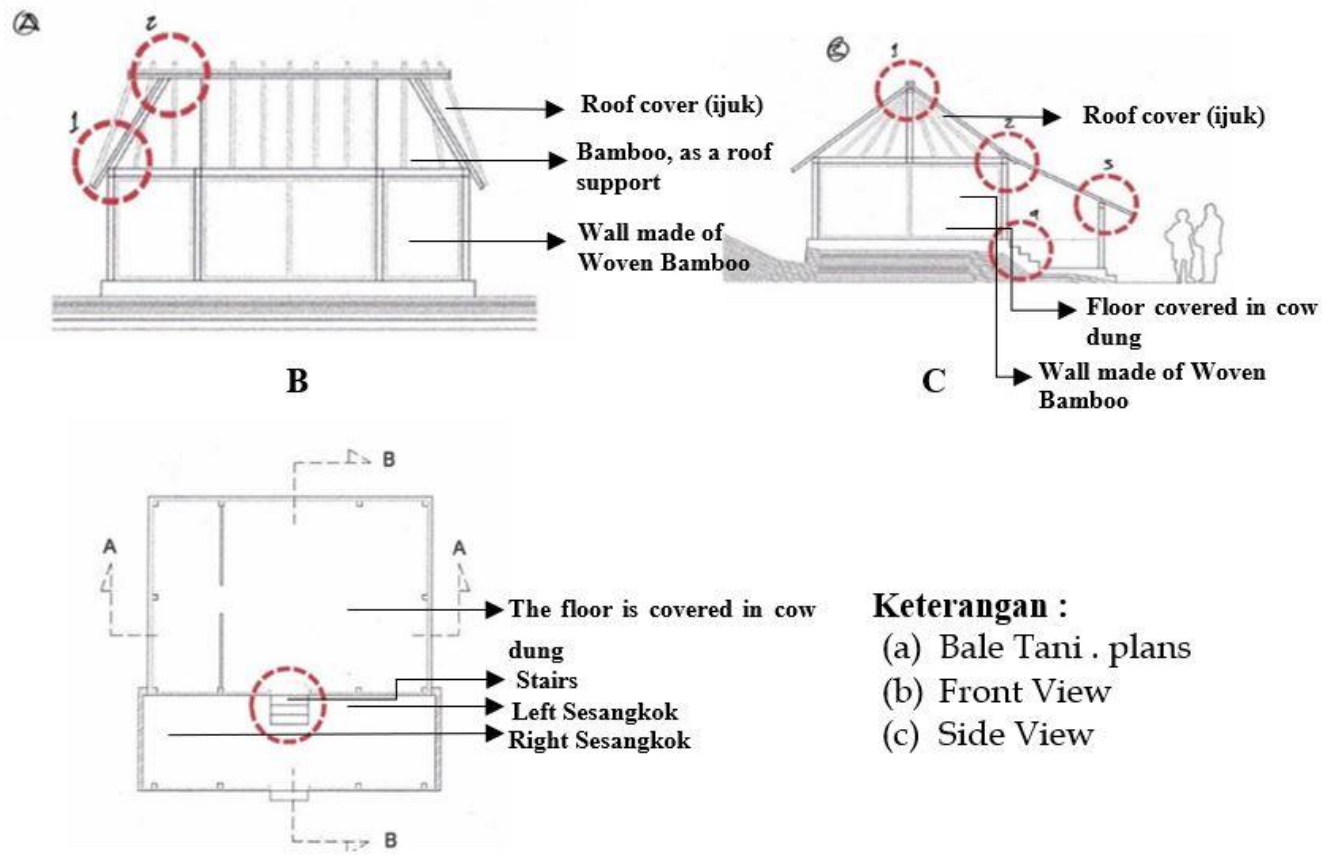

Keterangan :

(a) Bale Tani · plans

(b) Front View

(c) Side View

$\mathbf{A}$

Figure 3. Limbungan House

(Author, 2020)

The Limbungan Traditional Village is known for its sacred source because the Limbungan people believe in Mount Rinjani as a source of magic in Lombok. Mount Rinjani is the residence of the goddess Anjani who is highly respected by the Sasak tribe itself. The people of Bale Tani all work as farmers. The shape of the Bale Tani itself symbolizes the microcosm or the small world. The microcosm is the relationship between God and man and man and man. The towering shape at the back symbolizes the relationship between humans and God, while the top part of the roof symbolizes the relationship between humans and each other. 
The traditional Bale Tani traditional house depicts the relationship between humans and humans must be balanced, ancestors and God Almighty. The division of space in traditional houses is divided into two parts: the outside and inside. The outer part in question is a spoon. When people enter the house will be faced with a Sesangkok or living room. To go to Bale Dalem, we have to pass a ladder with three to four steps. This number of steps symbolizes God, ancestors, and fellow human beings.

There are stored meanings that can be seen from the Bale Tani building in the Limbungan hamlet, namely, balancing the relationship between humans and God Almighty and with nature (Mount Rinjani) and always being humble or respecting each other. All traditional Limbungan buildings (Bale Tani) use a blend of natural materials (Natural) without brick walls. The Limbungan community has forest areas and agricultural fields, which the ancestors intended as a natural balance.

The Limbungan community has forest areas and fields that function differently according to the uses of the local Limbungan community. A vast forest that is still protected, and in this forest forms a ritual space. There are the Limbungan people's tombs in the forest, which residents visit every particular time. In the forest, there is a ritual place when visiting ancestral graves. The meaning of the ritual is, praying at the ancestral graves (praying for the deceased). Moreover, in the forest, there are also woods and bamboo to build houses, bamboo bark (woven bamboo) for walls, and bamboo ropes to tie the top and walls of the house (Figure 3). As for the agricultural fields themselves, the Limbungan people make their rice fields, fields, and gardens, and some of the Limbungan communities themselves work as farmers.

The formation of the elements that make up the residential space uses Bale, Panteq, which consists of Lumbung and Berugaq, and the term in the traditional settlements of Limbungan Hamlet. There are houses lined up called suteran. The Suteran group is called a hut (village). Between the suteran, there is an alley or culvert.

The traditional settlement area consists of permanent houses, traditional houses, public facilities in mosques, and prayer rooms. The development of traditional houses is clustered in the western and eastern end areas, surrounded by hedges of living plants in the traditional residential area of Limbungan. There are rivers, rice fields, gardens, cowshed houses, village offices, and others around the traditional settlements of Limbungan.

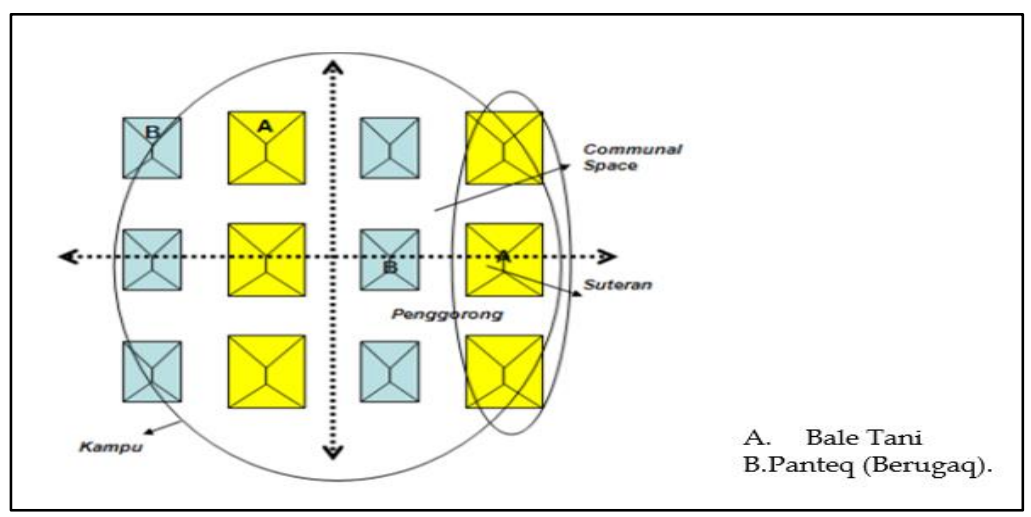

Figure. 4. House Element Formation

Source: (Preservation of Traditional Settlement Patterns of the Sasak Tribe, Dusun Limbungan, East Lombok Regency) 


\section{Limbungan Soil Conservation Concept}

The concept of building traditional Sasak houses is that the Sasak people adapt to the needs of their families and groups. The room (rong) is divided into Bale Inan (main room), including the outer bale (sleeping room) and bale dalem in the form of a place to store property, a room for mothers to give birth, as well as a place where the body is buried before burial. That must be prepared when building a traditional Sasak Limbungan House, such as wood, bamboo, woven bamboo (bedek), straw (ijuk), or alang - alang, cow dung, and sap Bajur tree. For the Limbungan indigenous community, the house itself has an important function and meaning in life. Therefore, it is necessary to carefully calculate to find a good time, day, date, and month to build a house. The Sasak people to find the right time are guided by the large board (derived from the primbon) of Adam's tapel and Tajul Muluq. Not all Sasak indigenous people can determine a good day. When ordinary people want to build a house, they have to ask about the rules and an excellent time to build a house to the customary leader.

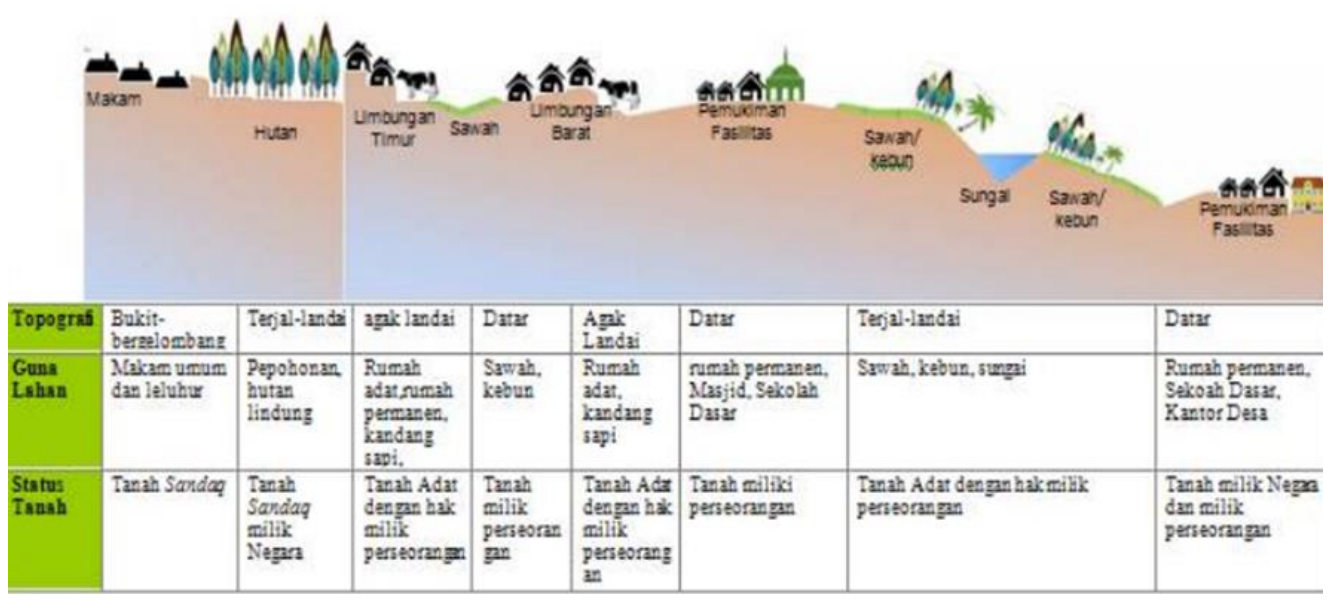

Figure. 5. Limbungan Traditional House Settlement Pattern

Source: (Preservation of Traditional Settlement Patterns of the Sasak Tribe, Dusun Limbungan, East Lombok Regency)

The indigenous people of Lombok believe that the best time to start building a house is in the third and twelfth months of the Sasak calendar, namely the month of Rabiul Awal and the month of Zulhijjah on the Islamic calendar. Moreover, for taboos (avoided when building a house) in the month of Muharram and the month of Ramadan. According to customs and beliefs, it invites many disasters, such as fires, it is difficult to get a fortune.

\section{Local Wisdom of the Limbungan Community (Bale Tani) in Traditional House Design}

The Limbungan indigenous community, based on the research results, is known to have local wisdom values. The Limbungan community has local knowledge about the ecological conditions of the Limbungan traditional house. It has the value of local wisdom in managing forest areas from the various natural resources in it (Fig. 7 \& 8). According to Johnson (1996), local wisdom is a collection of knowledge created from generation to generation in a group of people who blend with nature. Local wisdom is a knowledge that develops in society from generation to generation and wisely becomes the norms and 
wise values in a society that is one with nature. Cold climatic conditions, due to the community itself, standing at the foot of Mount Rinjani.

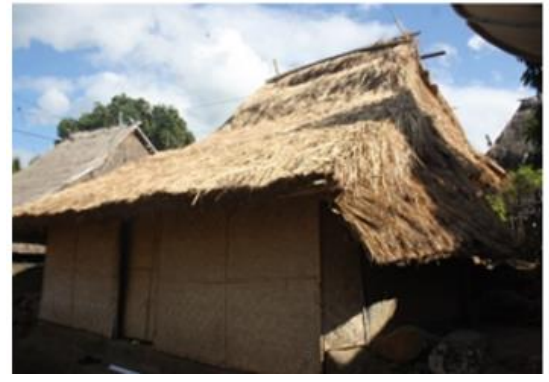

Figure 6. Bale Tani Traditional House (Author, 2020)

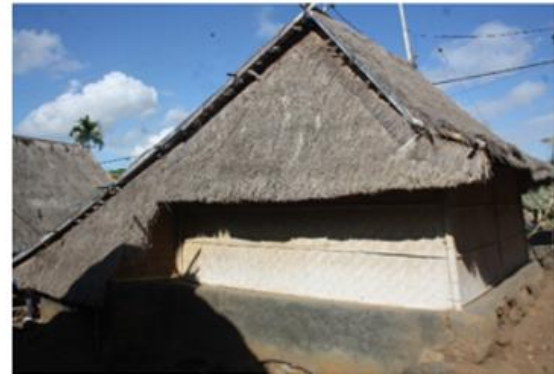

Figure 7. Bale Tani Traditional House (Author, 2020)

The building of this traditional house has not changed from the past. Namely, the walls are in bedek (fence of bamboo), roofed with woven weeds, and earthen floors (Fig. 8). However, local people's lives have been slightly contaminated with modern times, but not in the buildings. The roof, the roof of the Sasak bale, is in the form of a pyramid made of thatch leaves and bamboo, which is easily found in the surrounding environment. Based on observations, when viewed from the outside, the roof is larger than the body of the house, the shape of the front roof protrudes downwards. The body position is bowed, which shows respect.

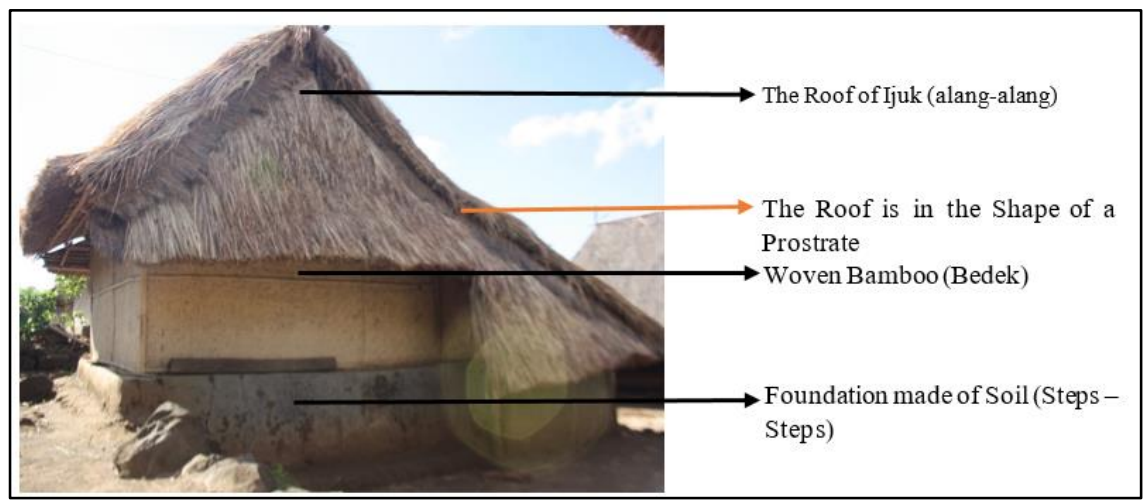

Figure 8. Local materials use for building elements (Author, 2020)

On the front and back, the walls are woven bamboo, the house's pillars where the walls are attached using bamboo, to tie the wall with poles using rattan, the materials used to make this wall simple, easy to obtain as soil and bamboo. Then the window, this traditional house has no window, during the day, the house will remain dark because there is no window as a gap for the sun to enter the house.

Lawang/Door There are two doors in the traditional house of Limbungan (bale tani), the first door is located at the front as a way in and out, and the second door is located in the middle as a liaison between the room and the terrace (sesangkok). Each door in each of these traditional bales simultaneously faces east (the direction of the house's orientation). 
The door of the house is made in a low position because when entering a Bale Tani House. To bow head reflects mutual respect and respect between guests and the house owner (the host). Moreover, lock a door using a wooden or bamboo stick with a value of trust in fellow Limbungan indigenous peoples.

The floor/terrace of a traditional Limbungan house comprises soil, Banten tree sap, and water. Uniquely, even if guests or visitors come and sit on the floor or terrace wearing white clothes, it will not stick, and during the rainy season, it will not fade. After that, it is then painted/smeared with 10 or 12 batteries taken from the black part when it is dry. The paint with batteries can last for approximately 3 to 4 years. If it is up to 3 years, then paint with the same material that has been used before.

The window, the traditional house of Limbungan does not have a window. During the day, it will be dark inside the house because it does not have a window as a gap for the sun to enter the traditional bale Limbungan. Sunlight enters through the doors, terraces, and cracks in the walls made of woven bamboo. The traditional house of Limbungan may not have a window because this traditional house of Limbungan is located in mountain Rinjani with cold weather to avoid cold air, and no windows are made in the house.

The stairs in the Limbungan traditional house are made of the same material as the terrace. Outside and inside, there are 2 (two) stairs. Outside the house, there are two stairs elongated in shape and used by the community to greet each other and greet each other. Inside the bale tani, there are 3 to 5 steps of stairs. In the Limbungan traditional house itself, stairs very rarely found as many as four steps. In Islam, the Limbungan community believes the number of stairs is 5 (five), reflecting the number of prayer times and the number of pillars of the Islamic faith.

Room. The room, consisting of a bedroom and a sesangkok. The bedroom is used to store valuables and valuables and activities, sleeping for daughters and wives. The bedroom is also used when family members give birth or die (died), starting from being bathed to being wrapped in a shroud and placed inside.

Furthermore, activities of the space in the traditional village of Limbungan have a function. Namely, the bedroom serves as a place for girls and wives to do activities, while the terrace serves to receive guests or a place for families to chat. The terrace is also used to receive guests and chat if there is a family who visits.

\section{Traditional Bale Tani House and Natural Air circulation}

The traditional house of Limbungan (Bale Tani) has no windows or ventilation. The climatic condition of the Limbungan traditional house itself is caused by the position of traditional settlements in the mountainous area of Mount Rinjani. The location of the Sasak Limbungan traditional house is in a hilly area at the foot of Mount Rinjani with quite cold air, so to avoid cold air, no windows are made in the house, so that air can enter the room, through the main door (Front Terrace) and from the cracks. In the Limbungan area itself, the circulation of sunlight enters through the doors, terraces, and cracks in the walls made of woven bamboo. Woven bamboo became the walls of the traditional Limbungan building. Wisely, the Limbungan community continues to seek movement within the house. Nevertheless, the air movement is regulated only at the front door and the middle door inside the Bale Tani House (Fig. 9). 


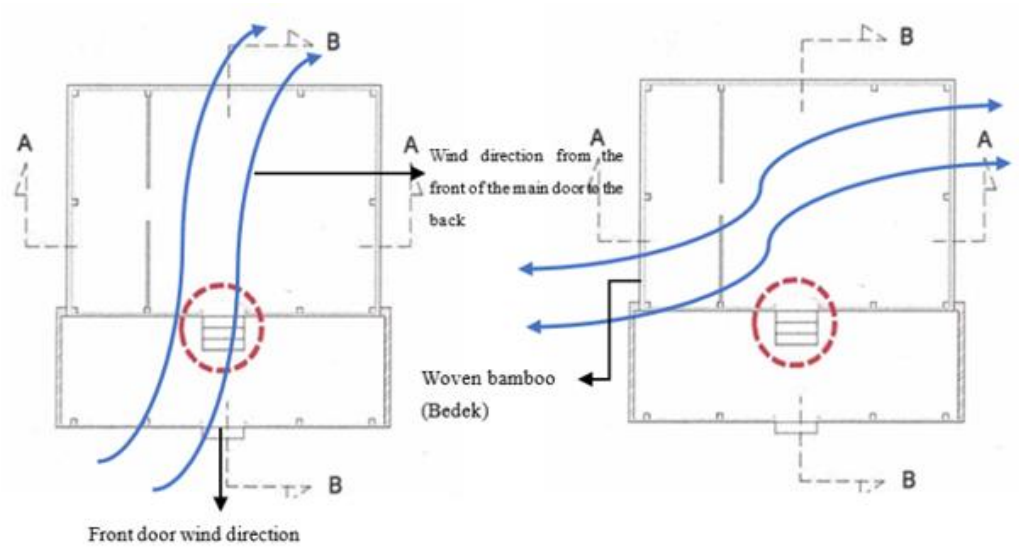

Figure 9. Bale Tani Wind House Illustration (Author, 2020)

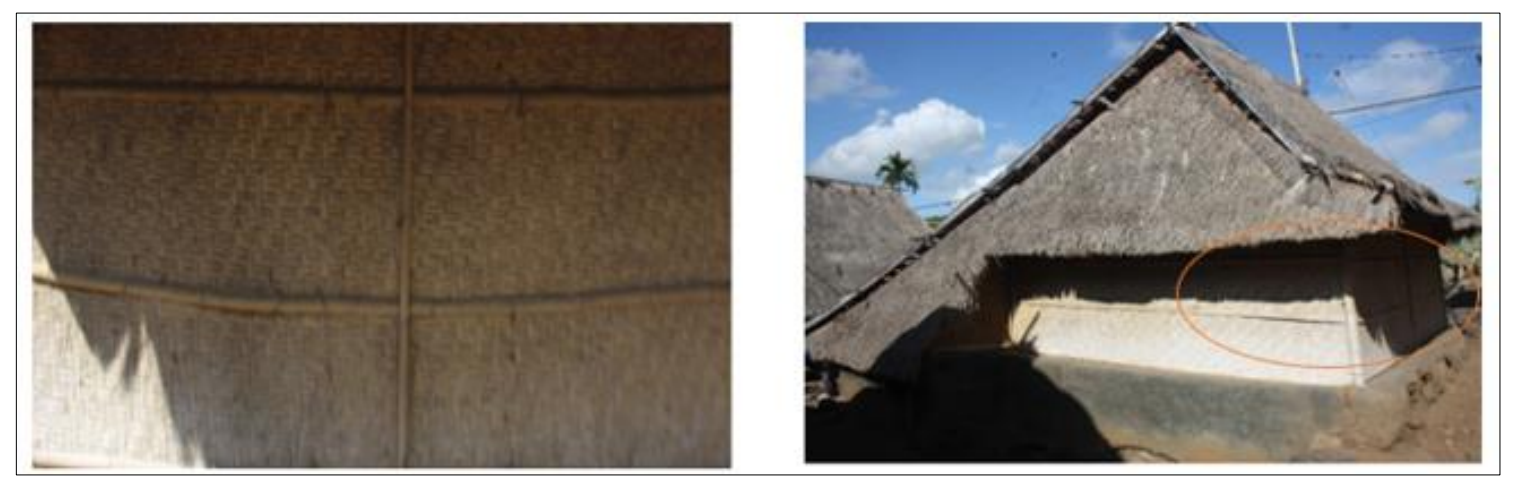

Figure 10.Woven Bamboo as Air circullation to the house

(Author, 2020)

There are very few air, light, or sunlight gaps in the traditional bale Limbungan (Bale Tani) called bedek (Fig. 10). The Bale Tani does not have a window is also that the local community is to avoid the easy entry of thieves who will enter the Limbungan traditional house.

\section{The Direction of the Limbungan Traditional Building}

All traditional buildings in Limbungan face east, related to the factors of trust and security. All bale tani buildings face east because they follow the direction of Mount Rinjani, which the Sasak people highly respect. Limbungan shows the formation of the Sasak (Lombok) community that the young must also take care of the old. If the enemy attacks, then the younger must attack first to protect the older (lingsir). There are philosophical values in it that parents must provide a role model and ancestral traits to their children. The picture below shows, the further north the traditional house of Limbungan is and the closer to Mount Rinjani, the higher the level of the sacredness of the traditional Limbungan building. 


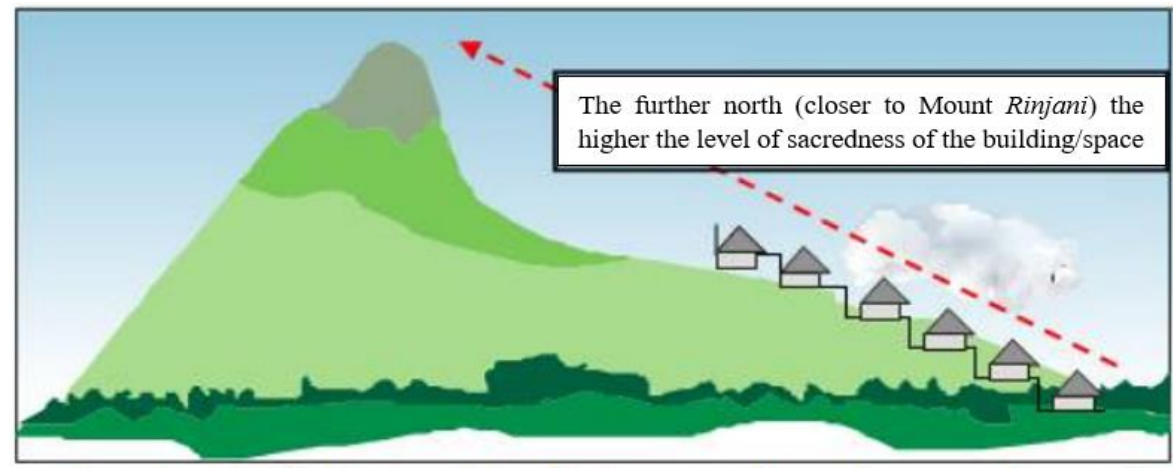

Figure. 11. Limbungan Traditional Building Orientation Direction Source: (Preservation of Traditional Settlement Patterns of the Sasak Tribe, Dusun Limbungan, East Lombok Regency)

\section{Earthquake Resistant Design of Limbungan traditional building}

One of the Limbungan structure constructions consists of a pole made of bamboo and a wall made of woven bamboo (Bedek). At the top of the building, the roof of the building is made of a collection of thatch/reeds. The closeness of nature shows that all the necessities of life for the community can be taken from nature, both residential buildings and food and medical materials. Moreover, it can be said that one hundred percent of traditional house building materials can be taken from nature, such as roofs made of straw and wood as a roof binder with alang - alang. Moreover, it can be seen from the technology of the Sasak traditional house in Lombok. It is said to have the advantage of being earthquake resistant (google, accessed June 26, 2019).

\section{CONCLUSION}

Local wisdom of the traditional house community is adaptive to the natural environment adapted to the availability of natural materials. Furthermore, the community has the philosophical value of local wisdom, which is still used today to build a traditional residential environment. The traditional house of Limbungan (Bale Tani) has local wisdom that adapts to natural resources, geographical location, and culture of the mountainous climate area of Mount Rinjani so that it raises many potentials to become one of the Archipelago Architectural conservation houses. A conservation method is needed that can be carried out by involving all stakeholders to be able to maintain the local wisdom of Nusantara Architecture.

\section{REFERENCES}

Álvarez-García, J., Maldonado-Erazo, C. P., Río-Rama, M. de la C. Del, \& CastellanoÁlvarez, F. J. (2019). Cultural heritage and tourism basis for regional development: Mapping of scientific coverage. Sustainability (Switzerland), 11(21). https://doi.org/10.3390/su11216034

Budihardjo, E., \& Sidharta. (1989). Konservasi Lingkungan dan Bangunan Kuno Bersejarah di Surakarta, Indonesia. UGM Press.

Fajarini, U. (2014). Peranan Kearifan Lokal Dalam Pendidikan Karakter. SOSIO DIDAKTIKA: Social Science Education Journal, 1(2). https://doi.org/10.15408/sd.v1i2.1225 
Golany, G. S. (1995). Etics and Urban Design; Culture, Form, and Environment. Wiley.

Haryanto, J. T. (2014). Kearifan Lokal Pendukung Kerukunan. 201-213.

Hilman, I., \& Hendriawan, N. (2018). Local Wisdom of Indigenous Community of Kampung Dukuh as Culture Preservation in Ciroyom Village, Cikelet district, Garut Regency, West Java Province. IOP Conference Series: Earth and Environmental Science, 145(1). https://doi.org/10.1088/1755-1315/145/1/012028

Hilman, Iman, Hendriawan, N., \& Sunaedi, N. (2019). Culture of Local Wisdom of Kampung Kuta Community in Facing Climate Changes in Ciamis Regency, West Java. IOP Conference Series: Earth and Environmental Science, 338(1), 0-7. https://doi.org/10.1088/1755-1315/338/1/012006

Hilman, Iman, \& Sunaedi, N. (2017). Revitalization of Local Wisdom in Environmental Education. February. https://doi.org/10.2991/icge-16.2017.74

Johnson, A. G. (1996). Human Arrangement An Introduction To Sociology (Fourth Edi). Brown and Benchmark Publisher.

Milton, C. J. (2021). Theodore Roosevelt. Encyclopedia Britannica. In Encyclopedia Britanica.

Raihani, Aljuneid, S. K., \& Awang, M. Z. (Eds.). (2015). Proceedings International Conference of Islamis Education (p. 781). UIN Malik Ibrahim, Malang.

Soeroto, M. (2003). Kepekaan Sosio-Kultural Arsitek. In Dari Arsitektur Tradisional Menuju Arsitektur Indonesia.

Suharjanto, G. (2011). Membandingkan Istilah Arsitektur Tradisional Versus Arsitektur Vernakular: Studi Kasus Bangunan Minangkabau dan Bangunan Bali. ComTech: Computer, Mathematics and Engineering Applications, 2(2), 592. https://doi.org/10.21512/comtech.v2i2.2808

Tanudirjo, D. A., Yuwono, J. S. E., \& Wardoyo Adi, A. M. (2019). Lanskap Spiritual Situs Liyangan. Berkala Arkeologi, 39(2), 97-120. https://doi.org/10.30883/jba.v39i2.474

Titisari, E. (2017). Intangible Cultural Heritage Candi Sumberawan Dalam Perspekstif. May.

Widayati, N. (2002). Permukiman Pengusaha Batik Di Laweyan Surakarta. Pascasarjana Fakultas Sastra Universitas Indonesia, Jakarta.

Widiana, F., \& Wikantiyoso, R. (2018). IImplementasi Kearifan Lokal dalam Strategi Pengembangan Wisata Pantai Sendang Biru untuk Pelestarian Pulau Sempu. | 7 | LOCAL WISDOM, 10(1), 7-13. 